\title{
PENGEMBANGAN SISTEM INFORMASI PENJADWALAN KONSULTASI DOSEN FAKULTAS ILMU KOMPUTER UNIVERSITAS BRAWIJAYA
}

\author{
Yusi Tyroni Mursityo ${ }^{1}$, Djoko Pramono ${ }^{2}$, Azhar Ogi ${ }^{3}$ \\ 1, 2, 3 Jurusan Sistem Informasi, Fakultas Ilmu Komputer, Universitas Brawijaya \\ Jalan Veteran No.8 Kota Malang \\ Telp, Fax: 0341-577911 \\ E-mail:yusi_tyro@ub.ac.id ${ }^{1}$,djoko.jalin@ub.ac.id ${ }^{2}$,zharlet@ub.ac.id ${ }^{3}$
}

\begin{abstract}
ABSTRAKS
Urgensi dari mahasiswa dengan dosen sangat beragam, seperti mereka yang ingin menemui dosen untuk melakukan bimbingan skripsi, untuk melakukan validasi krs, untuk mempresentasikan project akhir dan lain sebagainya yang diharuskan untuk melakukan konfirmasi dengan dosen sebelum bertemu. Keterbatasan mahasiswa yang tidak mengetahui antara jadwal luang dengan kesibukan setiap dosennya membuat mahasiswa merasa kebingungan dan cenderung kelelahan karena tidak adanya kepastian waktu dari dosen yang mereka ingin temui. Beberapa kasus pun terjadi pada dosen yang harus menghadiri aktivitas yang mendadak dan harus dilakukan penjadwalan ulang dengan mahasiswanya. Seorang dosen tidak mungkin memberi pesan broadcast ke mahasiswa atau mengirim pesan ke setiap mahasiswa. Diusulkan sebuah solusi aplikasi yang dapat membantu untuk menangani permasalahan pada sistem reservasi antara mahasiswa dan dosen ialah dengan cara mengembangkan sistem informasi penjadwalan tatap muka dan konsultasi mahasiswa dengan dosen ini untuk mengoptimalkan dan mempermudah proses janjian antara dosen dan mahasiswa melalui media desktop ataupun mobile berbasis website. Aplikasi ini diharapkan bisa meningkatkan efektifitas dan efisiensi proses komunikasi dosen dan mahasiswa terutama dalam pengerjaan tugas akhir mahasiswa.
\end{abstract}

Kata Kunci: penjadwalan, pengembangan sistem informasi, komunikasi, konsultasi

\begin{abstract}
The urgency of students and lecturers is very diverse, such as those who want to meet the lecturer to conduct thesis guidance, to validate the CRS, to present the final project and so on which are required to confirm with the lecturer before meeting. The limitations of students who do not know between their free schedule and the busyness of each lecturer make students feel confused and tend to be tired because there is no certainty of time from the lecturer they want to meet. Several cases also occurred in lecturers who had to attend sudden activities and had to reschedule with their students. A lecturer may not broadcast messages to students or send messages to every student. An application solution is proposed that can help to deal with problems with the reservation system between students and lecturers by developing a face-to-face scheduling information system and studentlecturer consultation to optimize and simplify the appointment process between lecturers and students via desktop or mobile media based on websites. This application is expected to increase the effectiveness and efficiency of the communication process for lecturers and students, especially in the processing of student final assignments.
\end{abstract}

Keywords: scheduling, information system development, communication, consulting

\section{PENDAHULUAN}

Fakultas Ilmu Komputer (FILKOM) Universitas Brawijaya (UB) ialah salah satu fakultas yang memiliki banyak mahasiswa dan dosen serta staf akademik lainnya (PSIK FILKOM UB, n.d.). Namun dibalik mahasiswa yang sedang sibuk dengan akademis, terdapat dosen yang sedang terlibat langsung dengan kegiatan atau aktivitas sebagai pendukung FILKOM. Sehingga tak jarang beberapa dosen memiliki jadwal yang sangat padat dan jarang sekali berada diruangannya. Secara akademik, mahasiswa mampu melakukan komunikasi dengan dosen melalui media sosial hanya di waktu atau jam kerja saja dan harus disertai dengan sapaan atau pembukaan yang sopan. Acapkali ketika mahasiswa mengirim pesan kepada dosen, mahasiswa tidak mendapatkan balasan dari dosen yang dimana mahasiswa mengetahui bahwa dosen tersebut sedang dalam status online. Bagi dosen, mendapati banyak pesan yang masuk tiap harinya mengakibatkan dosen tidak mampu membuka atau mengabaikan semua pesan yang masuk.

Urgensi dari mahasiswa dengan dosen sangat beragam, seperti mereka yang ingin menemui dosen untuk melakukan bimbingan skripsi, untuk melakukan validasi KRS, untuk mempresentasikan project akhir dan lain sebagainya yang diharuskan untuk melakukan konfirmasi dengan dosen sebelum bertemu. Keterbatasan mahasiswa yang tidak mengetahui antara jadwal luang dengan kesibukan setiap dosennya membuat mahasiswa merasa 
kebingungan dan bahkan mereka cenderung kelelahan karena tidak adanya kepastian waktu dari dosen yang mereka ingin temui. Beberapa kasus pun terjadi pada dosen yang harus menghadiri aktivitas yang mendadak dan harus dilakukan penjadwalan ulang dengan mahasiswanya.

Dari permasalahan dan urgensi diatas, maka akan diusulkan sebuah solusi yang dapat membantu untuk menangani permasalahan pada sistem reservasi antara mahasiswa dan dosen ialah dengan cara mengembangkan sistem informasi penjadwalan tatap muka dan konsultasi mahasiswa dengan dosen ini untuk mengoptimalkan dan mempermudah proses janjian antara dosen dan mahasiswa melalui media desktop ataupun mobile berbasis website. Tidak hanya itu, sistem informasi ini akan diintegrasikan dengan Google Calendar yang tersemat pada handphone android dosen (Rampton, n.d.). Semua masukan dari mahasiswa akan masuk ke dalam catatan atau event pada Google Calendar dosen. Sehingga pada proses penjadwalan ulang dosen hanya perlu menandai waktu yang harus di jadwalkan ulang saja. Dari solusi diatas, maka proses penjadwalan pertemuan atau tatap muka dan konsultas antara mahasiswa dan dosen lebih mudah, dari sudut pandang mahasiswa mereka tidak perlu merasa kebingungan untuk mencari jadwal dosen, dan dari sudut pandang dosen mereka tidak harus membalas pesan satu persatu ke mahasiswa yang ingin melakukan pertemuan.

Langkah pengerjaan dimulai dengan melakukan analisis proses bisnis (Weske, 2012), dilanjutkan dengan analisis kebutuhan, merancang sistem, mengimplementasikan, analisis pengujian (Pressman, 2009) dan penerimaan terhadap sistem yang telah dikembangkan (Whitten \& Bentley, 2007). Penelitian ini berfokus pada pembahasan pengembangan aplikasi sistem informasi pada bagian sistem booking jadwal dosen dari mahasiswa, memanajemen waktu luang dosen, dan penjadwalan ulang di FILKOM.

\section{PERANCANGAN}

Pemodelan proses bisnis yang pertama ialah penyusunan jadwal yang dilakukan oleh dosen. Penyusunan ini guna untuk menampilkan jadwal dosen yang pada saat itu dapat dilakukan pertemuan. Jadwal yang telah disusun dapat dilihat oleh mahasiswa melalui sistem informasi website dan dapat dipilih sesuai keinginan mahasiswa. Pemodelan pertama ini ditunjukkan dalam gambar 1 berikut:

Dari proses bisnis rekomendasi (to-be) diatas dimana sistem yang memiliki fungsional yang dapat menyimpan jadwal dosen. Jadwal yang dimaksud ialah jadwal dosen yang memiliki status 'tersedia' agar bisa di lihat dan dipilih oleh mahasiswa. Sehingga diharapkan mahasiswa tidak memerlukan konfirmasi dosen terkait untuk melakukan pertemuan.

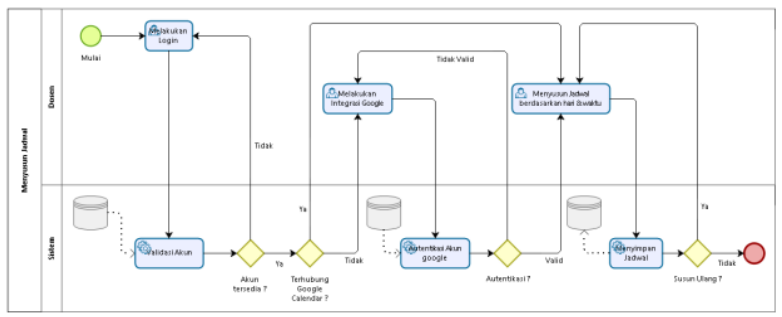

Gambar 1. BPMN Penyusunan Jadwal (to be)

Pemodelan bisnis selanjutnya ialah Penjadwalan Pertemuan yang dilakukan oleh mahasiswa. Proses ini dapat dilakukan setelah dosen melakukan proses bisnis penyusunan jadwal sebelumnya. Melalui sistem ini, mahasiswa diwajibkan untuk melakukan login atau masuk ke dalam sistem menggunakan akunnya untuk menghindari proses spam terhadap sistem. Setelah mahasiswa menetukan dan memilih jadwal dosen, maka jadwal yang dipilih akan masuk ke dalam Google Calendar dosen pada bagian events. Pemodelan proses bisnis ini di gambarkan pada gambar 2.

Dari proses bisnis rekomendasi (to-be) diatas dimana sistem yang memiliki fungsional untuk mahasiswa dapat memilih jadwal dosen dan sistem dapat mengirimkan data permintaan ke aplikasi Google Calendar dosen. Sehingga setiap kali mahasiswa memilih jadwal maka notifikasi akan diterima oleh dosen yang dituju. Diharapkan dari proses bisnis ini mampu mengurangi proses mengirim pesan lewat social messenger dan menambah efesiensi waktu.

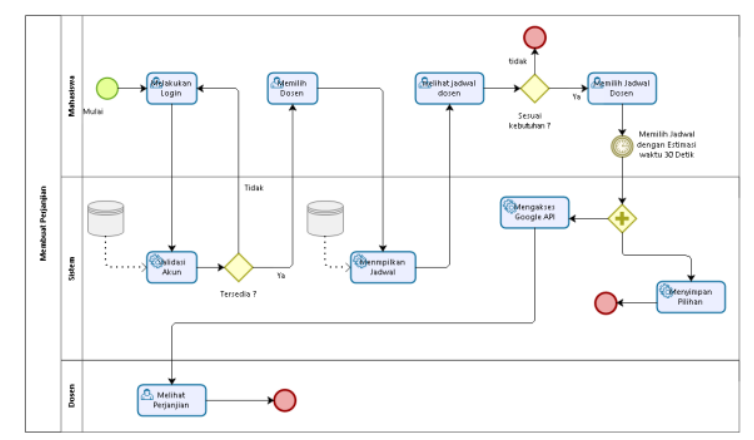

\section{Gambar 2. BPMN Penjadwalan Pertemuan (to be)}

Proses bisnis yang terakhir yaitu untuk melakukan penjadwalan ulang terhadap jadwal yang sebelumnya telah ditentukan, namun terdapat beberapa alasan yang mengharuskan dilakukannya penjadwalan ulang atau bahkan pembatalan dari dosen untuk mahasiswa. Penjadwalan ulang pada sistem memiliki 2 opsi, yaitu penjadwalan ulang rekomendasi dari dosen dan penjadwalan ulang dari mahasiswa. Proses bisnis ini akan digambarkan pada gambar 3 berikut: 


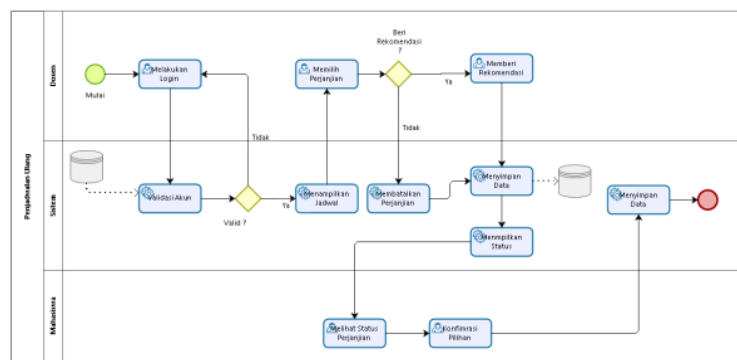

Gambar 3. BPMN Penjadwalan Ulang (to be)

Dari proses bisnis rekomendasi (to-be) diatas dimana sistem yang memiliki fungsional yang dapat melakukan penjadwalan ulang. Proses penjadwalan ulang diharuskan mahasiswa melakukan konfirmasi terhadap perubahan jadwal yang diajukan oleh dosen melalui sistem. Diharapkan dari proses bisnis ini dapat menambah kepastian mahasiswa untuk melakukan pertemuan dengan dosen dan mendapatkan kabar yang sesuai ketika dosen melakukan pembatalan pada jadwal yang sebelumnya telah dipilih.

Selanjutnya digambarkan diagram UML dengan use-case untuk menggambarkan tingkah laku dari sistem (Booch, Rumbaugh daN Jacobson 1998) (Kruchten 2000). Pada diagram use-case Gambar 4 terdapat 13 use-case diantaranya 7 use-case dengan aktor dosen, 3 use-case untuk aktor mahasiswa dan 3 use-case untuk mahasiswa dan dosen. Aktor pengguna digambarkan sebagai generalisasi aktor mahasiswa dan dosen untuk melakukan login sistem terlebih dahulu sebelum menggunakan sistem secara penuh. Jika pengguna tidak atau belum memiliki akun pada sistem, pengguna dapat melakukan registrasi terlebih dahulu.

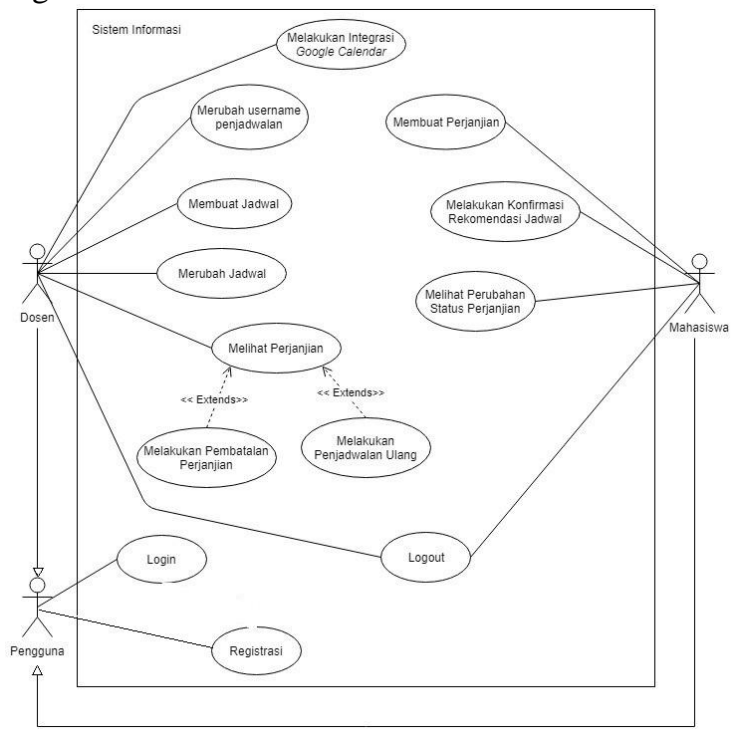

Gambar 4. Diagram use-case sistem penjadwalan

Gambar 5 menggambarkan diagram class untuk controller pada sistem. Class diagram dimodelkan berdasarkan kebutuhan yang telah dijabarkan sebelumnya, dan digunakan sebagai pedoman untuk melakukan tahap selanjutnya yaitu implementasi kode. Setiap controller memiliki fungsi yang berbeda, dan controller sendiri telah disediakan oleh framework Laravel yang di generalisasi oleh class Controller. Dari hasil analisis terdapat 8 controller yang mewakili kebutuhan sistem dan pengguna.

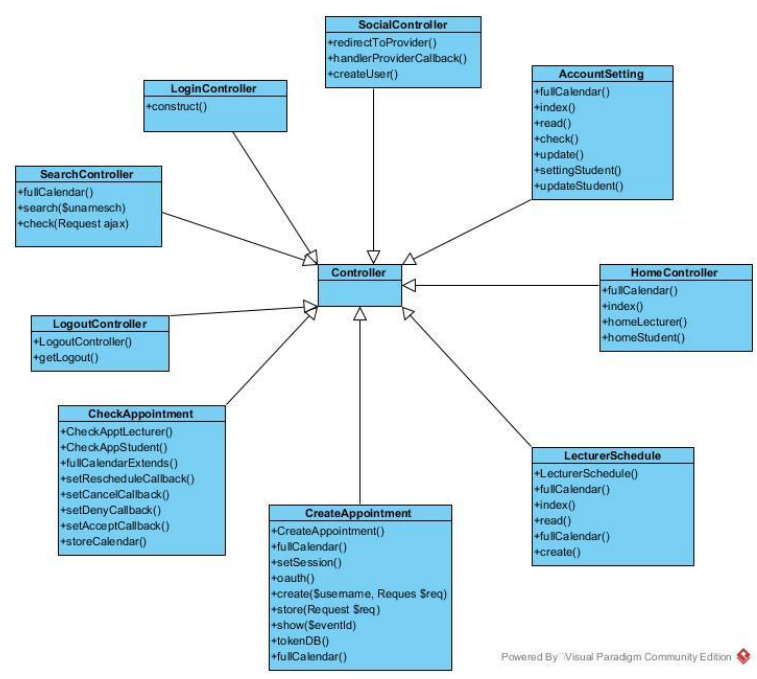

Gambar 5. Diagram Class Controller

Kemudian Gambar 6 menggambarkan entity relationship diagram berupa physical data model $(P D M)$ yang berisi 5 tabel serta relasinya yang akan diimplementasikan pada sistem yang akan dikembangkan.

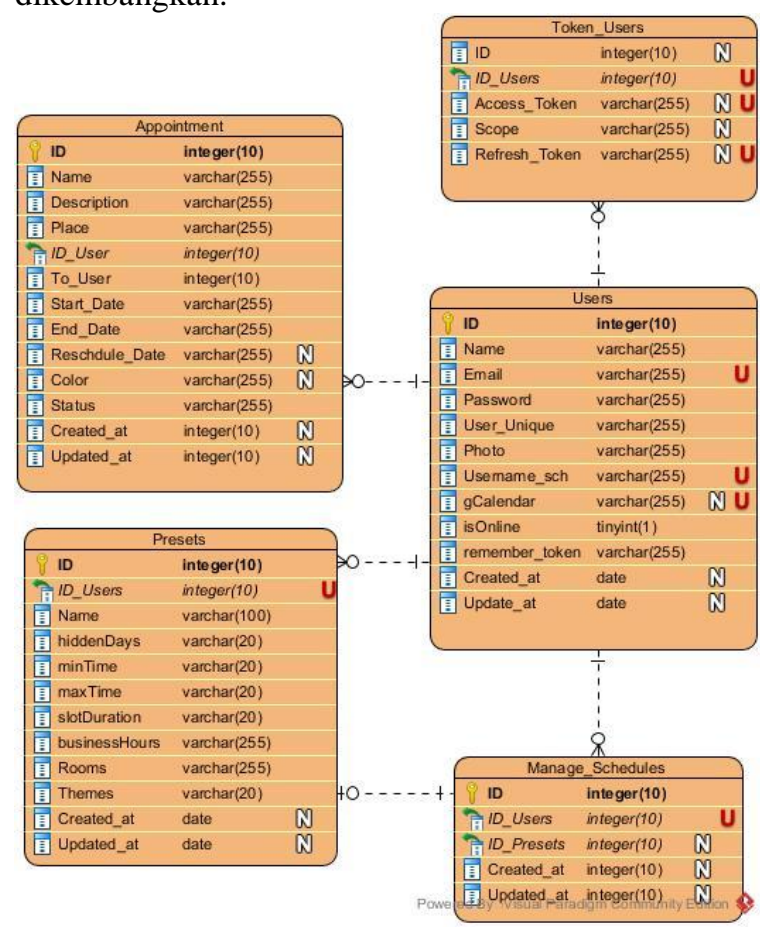

Gambar 6. PDM Sistem Penjadwalan 


\section{IMPLEMENTASI}

Implementasi antar muka secara garis besar untuk dosen adalah mengatur jadwal dan mengubah jadwal. Halaman yang berfungsi untuk dosen dalam mengatur atau menyusun jadwal yang dapat di pilih oleh mahasiswa ditunjukkan pada gambar 7. Pada halaman "Aturjadwal" juga terbagi 2 bagian yaitu bagian pengaturan dan preview jadwal.

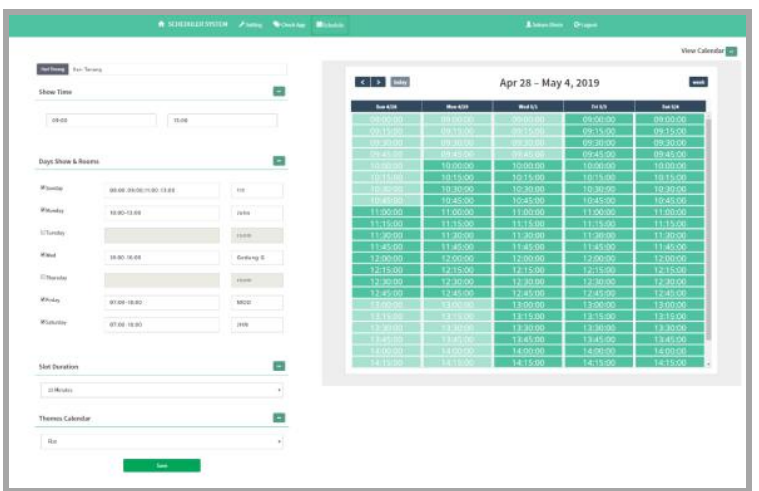

Gambar 7. Implementasi interface Aturjadwal

Kolom show time berfungsi untuk mengatur waktu yang tampil pada jadwal, sebagai contoh untuk jam 8 pagi hingga jam 4 sore. Sehingga pada jadwal hanya menampilkan waktu pukul 8 pagi hingga 4 sore. Kedua ialah kolom Days show yang berfungsi untuk mengatur hari yang tampil pada jadwal beserta waktu yang dapat dipilih oleh mahasiswa. Pada bagian preview jadwal, hanya blok yang berwarna putih saja yang dapat dipilih oleh mahasiswa. Ketiga ialah kolom Slot Duration yang berfungsi untuk mengatur waktu per slot ketika mahasiswa memilih salah satu jadwal. Sehingga dalam sekali pemilihan jadwal mahasiswa akan mendapatkan waktu lama perjanjian secara otomatis. Pada bagian preview juga dosen dapat melihat susunan jadwal berdasarkan mingguan.

Halaman selanjutnya yaitu gambar 8 berfungsi untuk dosen melakukan pengecekan sekaligus pembatalan atau perubahan jadwal dari perjanjian yang ada. Data Status perjanjian ditampilkan pada Appointment Table, dan memiliki indikator warna. Untuk indikator berwarna hijau berlaku pada perjanjian yang memiliki status active, indikator berwarna merah berlaku pada perjanjian yang memiliki status cancel, dan indikator berwarna ungu berlaku pada perjanjian yang memiliki status waiting. Untuk perjanjian yang berstatus waiting menunjukan bahwa perjanjian tersebut telah di jadwal ulang oleh dosen.

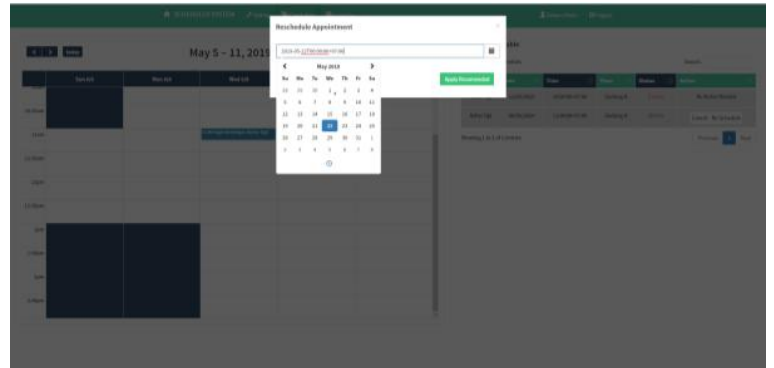

Gambar 8. Implementasi interface Penjadwalan Ulang

Untuk proses bagi mahasiswa akan membuat perjanjian dengan dosen diimplementasikan pada gambar 9 berikut:

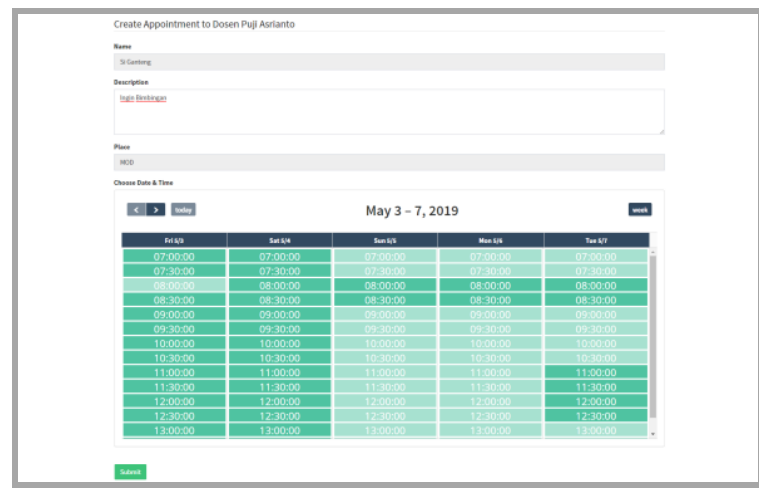

\section{Gambar 9. Implementasi interface CreateEvent}

Untuk mengakses halaman ini mahasiswa perlu mengetahui username penjadwalan dosen terlebih dahulu. Data yang akan dimasukan ke dalam perjanjian yaitu Nama pada kolom Name, Deskripsi pada kolom Description, dan Tanggal dan waktu pada kolom calendar Choose Date \& Time. Pada sistem, mahasiswa tidak diperbolehkan memilih tanggal tepat pada hari $\mathrm{H}$, sebelum hari $\mathrm{H}$, dan menimpa jadwal yang ada. Sehingga akan mencegah perjanjian yang tidak valid dan menghindari perjanjian yang dibuat secara dadakan oleh mahasiswa.

\section{PENGUJIAN}

Pengujian sistem pada tahap terbagi menjadi 2 jenis yaitu pengujian kebutuhan fungsional sistem dengan menggunakan metode pengujian black-box testing yaitu pengujian validasi, dan pengujian kebutuhan non-fungsional sistem dengan menggunakan metode pengujian compatibility testing. Pengujian kebutuhan fungsional sistem dilakukan menggunakan salah satu dari metode pengujian black-box testing yaitu pengujian validasi. Tujuan memilih menggunakan pengujian validasi ini ialah untuk dapat mengetahui kesesuaian antara kebutuhan pengguna dengan kebutuhan sistem yang telah dikembangkan. Pengujian dilakukan berdasarkan test case dan penguji mengikuti 
instruksi dari deskripsi pengujian disetiap test case yang ada.

Hasil dari pengujian kebutuhan non-fungsional dari sistem penjadwalan yang telah dikembangkan. Hasil yang ditampilkan merupakan screenshot hasil yang di keluarkan oleh aplikasi sortsite 5 versi trial yang digunakan untuk menguji compatibility setiap browser. Terkait kompatibilitas untuk masingmasing aplikasi browser tidak terdapat masalah apapun. Berikut hasil dari pengujian non-fungsional pada gambar 10 .

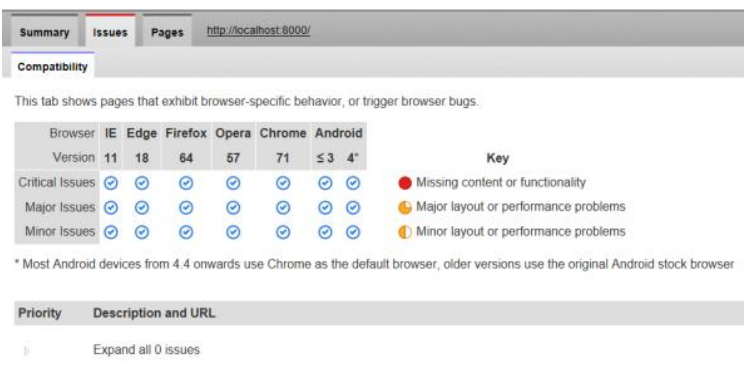

\section{Gambar 10. Hasil pengujian non-fungsional}

Pengujian User Acceptance Testing (UAT) dibagi menjadi 3 jenis berdasarkan klasifikasi aktor utama yang akan menggunakan sistem, diantaranya ialah aktor dosen dan mahasiswa. Proses pengujian UAT diawali dengan mendefinisikan terlebih dahulu kriteria penerimaan pengguna yang akan digunakan untuk melakukan pengujian serta pernyataan yang akan dinilai oleh pengguna sistem dengan menggunakan skala likert (Naik dan Tripathy 2008). Perancangan ini dibuat berdasarkan kebutuhan pengguna dan kebutuhan fungsionalitas sistem.

Kriteria yang digunakan: 1). Functional correctness and completeness (Berfokus pada terpenuhinya kebutuhan yang didefinisikan sebelumnya), 2). Usability (Berfokus pada tingkat kemudahan pengguna dalam menggunakan sistem), dan 3). Accuracy (Berfokus pada tingkat akurasi tanggal dan waktu).

Tabel 1. Hasil UAT

\begin{tabular}{|c|l|c|}
\hline No & Aktor & Tingkat Penerimaan \\
\hline 1 & Dosen & $100 \%$ \\
\hline 2 & Mahasiswa & $85.86 \%$ \\
\hline
\end{tabular}

Hasil UAT menunjukkan tingkat penerimaan diatas $80 \%$ sehingga disimpulkan dari pernyataan yang diubah menjadi data kualitatif bahwa dosen dan mahasiswa sangat sepakat dan antusias dengan adanya penerapan sistem informasi penjadwalan konsultasi.

\section{KESIMPULAN}

Pada proses yang direkomendasikan terdapat 3 proses bisnis, yaitu Penyusunan Jadwal yang dilakukan oleh dosen, Penjadwalan Pertemuan yang dilakukan oleh mahasiswa, dan Penjadwalan Ulang yang dilakukan oleh dosen. Dari kegiatan dosen menyusun jadwal yang tersedia, maka mahasiswa tidak perlu mengirim pesan kepada dosen. Selanjutnya jika dosen secara mendadak tidak dapat ditemui, maka dosen dapat menjadwal ulang perjanjian mahasiswa dan atau membatalkannya.

Proses implementasi dilakukan berdasarkan hasil perancangan sistem. Lalu proses pengujian sistem terbagi menjadi 2 jenis pengujian, yaitu pengujian fungsional dengan menggunakan metode pengujian black-box yang secara valid $100 \%$ sesuai dengan kebutuhan pengguna. Yang kedua adalah pengujian non-fungsional menggunakan metode pengujian compatibility dengan bantuan aplikasi sortsite 5 versi trial dengan hasil tanpa kendala pada aplikasi browser Google Chrome, IE, Edge, Mozilla Firefox, dan browser bawaan Android.

Tingkat penerimaan pengguna pada aktor dosen mendapatkan persentase penerimaan sebesar $100 \%$, dan aktor mahasiswa sebesar $82.86 \%$. Sehingga dapat disimpulkan bahwa kedua aktor tersebut sangat setuju dengan adanya penerapan sistem informasi penjadwalan tersebut. Saran pengembangan selanjutnya untuk perbaikan responsive pada antarmuka sistem informasi penjadwalan ketika diakses pada browser mobile.

\section{PUSTAKA}

Booch, Grady, James Rumbaugh, dan Ivar Jacobson. 1998. The Unified Modeling Language User Guide. Massachusetts: Addison Wesley.

Kruchten, Philippe. 2000. The Rational Unified Process -- An Introduction,. 2nd ed. Vancouver: Addison-Wesley-Longman.

Naik, Kshirasagar, dan Priyadarshi Tripathy. 2008. Software Testing and Quality Assurance : Theory and Practice. New Jersey: John Wiley \& Sons, Inc., Hoboken.

Pressman, Roger S. 2009. Software Engineering: A Practitioner's Approach, 7th International edition. New York: McGraw-Hill.

PSIK FILKOM UB. 2017. Academic Calendar. http://filkom.ub.ac.id/.

Rampton, John. 2020. The Ultimate Guide To Google Calendar. Agustus. https://www.calendar.com/google-calendarguide/.

Weske, Mathias. 2012. Business Process Management: Concepts, Languages, Architectures 2nd. Springer Berlin Heidelberg.

Whitten, Jeffrey L., dan Lonnie D. Bentley. 2007. System Analysis and Design Methods. New York: McGraw-Hill/Irwin. 